\section{Partial Flower Thinning Increases Shoot Growth, Fruit Size, and Subsequent Flower Formation of Peach}

\author{
Stephen C. Myers \\ Department of Horticulture and Crop Science, The Ohio State University, \\ Columbus, OH 43210
}

Amy T. Savelle

Department of Plant Pathology, University of Georgia, Athens, GA 30602

\section{Stuart Tustin}

The Horticulture and Food Research Institute of New Zealand, Havelock North, New Zealand

\author{
Ross E. Byers \\ Department of Horticulture, Virginia Polytechnic Institute and State \\ University, Winchester, VA 22602
}

Additional index words. chemical thinner, AMADS, Wilthin ${ }^{\mathrm{TM}}$, flower, thinning

\begin{abstract}
Partial thinning of peach (Prunus persica L. Batsch) during bloom to $50 \%$ of the necessary level by hand, and followed by adjustment hand thinning at 42 days after full bloom (DAFB) was compared to a similar degree of thinning accomplished entirely at 42 DAFB by hand. Partial flower thinning altered the distribution of fruit by diameter, increasing the percentage of large diameter $(\geq 62.0 \mathrm{~mm})$ fruit harvested compared to unthinned trees or trees thinned entirely at $42 \mathrm{DAFB}$. Although shoot number per limb was not altered by thinning time, the distribution of shoots by length was affected, increasing the percentage of long shoots $(\geq 20.0 \mathrm{~cm})$. Compared to unthinned trees and trees thinned at 42 DAFB, partial flower thinning increased the subsequent development of flower buds per shoot and the number of flower buds per node. Number of flower buds on the proximal five nodes of shoots $\mathbf{1 5 . 0 - 3 0 . 0} \mathrm{cm}$ in length was increased, although not on shoots 5.0-7.0 $\mathrm{cm}$ in length. Additional trials established that airblast spray application of AMADS was effective in achieving a similar level of thinning as that accomplished by partial flower thinning by hand in previous experiments. The degree of flower removal exhibited a linear response to chemical concentration. Fruit diameter on chemically flower-thinned trees was greater at adjustment thinning time, when compared to trees thinned by hand at 42 DAFB only. Distribution of fruit at harvest indicated a larger percentage of fruit $>65.0 \mathrm{~mm}$ in trees which received partial flower thinning in comparison to trees thinned at 42 DAFB only. As a result, overall crop value was increased, based on the commercial processing peach price structure at the time of harvest. Chemical name used: 1-aminomethanamide dihydrogen tetraoxosulfate (AMADS)
\end{abstract}

The relationship between larger fruit size and overall crop value is well-established in peach (Byers, 1989; Gardner et al., 1928). Fruit size is linearly correlated with fruit number per tree (Dorsey et al., 1926; Gardner et al., 1928). Increasing leaf area relative to fruit number results in larger fruit size (Weinberger, 1931), presumably as a result of the relative increase in assimilates available to fruit and shoots.

Responses to flower or fruit thinning, which effectively increases the leaf : fruit ratio, is well documented (Farley, 1923; Murneek et al., 1944; Weinberger, 1941) and include increased current season's shoot growth and

Received for publication 23 July 2001. Accepted for publication 16 Jan. 2002. Salaries and research support to S.C.M. provided, in part, by state and federal funds appropriated to the Ohio Agricultural Research and Development Center, The Ohio State Univ. Manuscript number HCS 01-02. flower bud formation (Byers et al., 1985; Havis, 1962; Hoffman et al., 1945; Myers, 1986; Tukey et al., 1939). Shoot length has been positively correlated with flower bud formation, fruit set, and fruit size (Corelli et al., 1991; Feucht, 1955).

The comparative advantage that flower or fruit thinning imparts to fruit, shoot, and flower development is influenced by thinning severity (Farley, 1923) and thinning time (Havis, 1962; Myers, 1986; Weinberger, 1941). Flower thinning provides the greatest response, with diminishing effect as time of thinning is delayed after flowering.

The benefits of flower thinning have long been noted (Murneek et al., 1944), but risks include an unpredictable natural fruit set that results in fruit abscission during the postbloom period, which in conjunction with flower thinning can result in significant crop reduction (Farley, 1923; Weinberger, 1941). Likewise, flower thinning in conjunction with late spring freezes poses the hazard of crop reduction (Byers et al., 1984; Hoffman et al., 1945). Further, hand thinning later in the season allows for selection of larger fruit, removal of deformed fruit, and more even spacing (Byers, 1989; Weinberger, 1941).

Hand removal of fruit, traditionally accomplished near the pit hardening stage of fruit development, remains the most common thinning practice. Thinning is a labor-intensive and expensive practice in peach culture (Byers, 1989; Byers et al., 1984; Murneek, 1944) although necessary, since failure to thin limits tree reserves that would otherwise be used for optimum fruit and shoot development and flower bud differentiation.

Attempts to chemically thin peach trees have been characterized by inconsistency, phytotoxicity, and lack of chemical industry pursuit of commercialization (Batjer et al., 1943; Byers, 1988; Byers et al., 1983). Desiccating agents have been used for flower thinning of peach trees (Byers et al., 1983); and one desiccating compound, 1-aminomethanamide dihydrogen tetraoxosulfate (AMADS) (Entek Corp., Brea, Calif.), has been registered by EPA for flower thinning of peach trees (Myers et al., 1993).

In considering both benefits and risks of flower thinning, partial flower thinning followed by additional adjustment thinning by hand at the pit hardening stage has been proposed as a potential strategy for dealing with risks such as variable thinning, natural fruit set, damage from spring frost, or damage caused to fruit by insects or disease (Byers et al., 1984; Weinberger, 1941). The effects of partial flower thinning followed by adjustment thinning by hand during the post-bloom period has not been reported.

The objectives of these studies were to: 1) evaluate the effect of partial thinning of flowers by hand $50 \%$ of the standard degree of thinning) and additional hand adjustment thinning performed at the pit hardening stage [42 d after full bloom (DAFB)] on fruit size, shoot growth, and flower bud formation in comparison with a similar total level of hand thinning accomplished entirely at 42 DAFB; and 2) establish a level of chemical thinning that would approximate the level of thinning attained during bloom in the previous experiment with additional hand thinning at 42 DAFB.

\section{Materials and Methods}

Expt. 1. Three scaffold limbs of similar vigor and size were selected and tagged on each of 12 irrigated, mature 'Redhaven' peach trees in Daleville, Va. The experiment was designed as a randomized complete block, with six treatments applied to tagged limbs in each of six, 2-tree blocks.

The following thinning treatments were applied to designated limbs at random: flowers or fruitlets remained unthinned, or were thinned at full bloom (0), 14 DAFB, 28 DAFB, $42 \mathrm{DAFB}$, or $56 \mathrm{DAFB}$. Treatments at 0 DAFB, 14 DAFB, or 28 DAFB were initially thinned to $\approx 6.5 \mathrm{~cm}$ apart followed by addi- 
tional thinning to $\approx 13 \mathrm{~cm}$ apart at 42 DAFB. At 42 DAFB and 56 DAFB, fruit were thinned once to a spacing of $\approx 13 \mathrm{~cm}$. All thinning treatments were performed by hand.

Fruit diameter and fresh weight were measured at harvest. Total number of shoots $3.0-8.0 \mathrm{~cm}, 8.0-20.0 \mathrm{~cm}$, and $>20.0 \mathrm{~cm}$ in length were measured during the subsequent dormant season. Distribution analysis of fruit by size and shoots by length was performed using the Pearson $\chi^{2}$ test for homogeneity (Fienberg, 1977). Total flower buds per shoot and number of flower buds on the proximal five nodes were measured on shoots 5.0-8.0 $\mathrm{cm}, 15.0-20.0 \mathrm{~cm}$, and $25.0-30.0 \mathrm{~cm}$ in length immediately prior to bloom of the subsequent season.

Expt. 2. Three limbs per tree, $\approx 2.5 \mathrm{~cm}$ in diameter, on 20 trees of 'Golden Queen' peach were selected for uniformity of size and vigor and tagged in Havelock North, New Zealand. 'Golden Queen' is a commonly grown, clingstone peach cultivar used for processing in New Zealand and Australia. The experiment was designed as a randomized complete block with five treatments and four replications. Treatments consisted of five concentrations of AMADS: 0 (control), $7.5 \mathrm{~mL} \cdot \mathrm{L}^{-1}, 10.0 \mathrm{~mL} \cdot \mathrm{L}^{-1}$, $12.5 \mathrm{~mL} \cdot \mathrm{L}^{-1}$, and $15.0 \mathrm{~mL} \cdot \mathrm{L}^{-1}$. Treatments were applied with an airblast sprayer calibrated to deliver $2100 \mathrm{~L} \cdot \mathrm{ha}^{-1}$ when trees averaged $73 \%$ full bloom. Applications were made to multiple row plots to simulate normal airblast application to a block of trees as described previously (Myers et al., 1993). Adjustment thinning was performed by hand at $\approx 6$ weeks following treatment. Data were collected from the interior trees in each plot.

Limb diameters were measured, and the number of flowers or fruit on each tagged limb were counted immediately prior to treatment, 6 weeks following treatment (before adjustment thinning), and 1 week following adjustment thinning. Fruit diameter was measured $5 \mathrm{~d}$ following hand thinning. Total number and yield of fruit per tree were measured at harvest. A random sample of 10 fruit from each tree was collected at each of the two harvest dates, and fresh weight and diameter were measured for each fruit. These values were used to calculate average fresh weight per fruit and to determine distribution of fruit into various size categories (packout). The percentage of fruit in each size category was determined, and distribution analysis was performed using the Pearson $\chi^{2}$ test of homogeneity (Fienberg, 1977).

\section{Results}

Expt. 1. Fruit diameter measurements confirmed earlier reports (Havis, 1962) that flower thinning provides the greatest response for increasing fruit size (Table 1). Likewise, partial flower thinning followed by adjustment thinning at 42 DAFB $(0+42)$ increased fruit size compared to a similar level of thinning accomplished entirely at 42 DAFB. Even delaying the initial thinning to $14 \mathrm{DAFB}$ $(14+42)$ was not as beneficial as earlier thinning in increasing fruit size. With fruit
Table 1. Percent distribution of fruit by diameter as influenced by thinning time of 'Redhaven' peach ${ }^{\mathrm{z}}$ Virginia.

\begin{tabular}{|c|c|c|c|}
\hline \multirow[b]{2}{*}{ Treatment } & \multicolumn{3}{|c|}{$\%$ Distribution by size ${ }^{x}$} \\
\hline & $\leq 55.0 \mathrm{~mm}$ & $>55.0<62.0 \mathrm{~mm}$ & $\geq 62.0 \mathrm{~mm}$ \\
\hline \multicolumn{4}{|l|}{ Thinned (DAFB) ${ }^{y}$} \\
\hline $0+42$ & 45.8 & 39.2 & 15.0 \\
\hline $14+42$ & 75.0 & 23.3 & 1.7 \\
\hline $28+42$ & 74.2 & 21.7 & 4.2 \\
\hline 42 & 71.4 & 25.2 & 3.4 \\
\hline 56 & 92.6 & 7.4 & 0.0 \\
\hline Unthinned (U) & 83.3 & 12.5 & 4.2 \\
\hline \multicolumn{4}{|l|}{$P$ value } \\
\hline All thinning treatments & \multicolumn{2}{|r|}{$<0.0001$} & \\
\hline$(0+42)$ vs. unthinned & & \\
\hline 42 vs. unthinned & & & \\
\hline$(0+42)$ vs. 42 DAFB & \multicolumn{2}{|r|}{$<0.0001$} & \\
\hline \multicolumn{4}{|c|}{$\begin{array}{l}{ }^{7} \text { Flowers or fruit initially thinned to } 6.5 \mathrm{~cm} \text { apart at bloom, } 14 \text { DAFB, or } 28 \text { DAFB } \\
\text { then adjusted to } 13 \mathrm{~cm} \text { apart at } 42 \text { DAFB. Fruit thinned once to } 13 \mathrm{~cm} \text { apart at } 42 \\
\text { DAFB or } 56 \text { DAB. } \\
\text { y Days after full bloom. }\end{array}$} \\
\hline
\end{tabular}

number constant (data not presented), partial flower thinning increased the percentage of fruit in the larger fruit size categories. As such, presumably the overall crop value would be enhanced (Byers, 1989; Gardner, 1928).

Thinning did not alter shoot number per limb as determined at the end of the season following treatment (Table 2). Among all thinning treatments, early thinning increased shoot length. The percentage of long shoots $(\geq 20.0 \mathrm{~cm})$ was increased and the percentage of shoots $\leq 8.0 \mathrm{~cm}$ in length was decreased. In comparing partial flower thinning $(0+42)$ to thinning only at $42 \mathrm{DAFB}$, partial flower thinning $(0+42)$ increased shoot growth $(P=0.1850)$, with the difference being primarily in the percentage of short shoots. Leaf area is strongly correlated with shoot length (Rieger et al., 1994); thus, because thinning increased shoot length, the leaf to fruit ratio over the season was increased. The effect of flower thinning on leaf development may have an influence on flower bud formation and fruit size (Murneek et al., 1944). Feucht (1955) and Corelli et al. (1991) have positively correlated flower bud formation, fruit set, and fruit size with shoot length.
Among thinning treatments, time of thinning was associated with flower bud number per shoot, per node, and on the proximal five nodes for shoots in all three shoot length categories (Table 3), with the highest flower bud number occurring in trees thinned at $0+$ 42 DAFB. Number of flower buds decreased linearly in all categories as time of thinning was delayed. Comparing partial flower thinning $(0+42)$ to thinning at 42 DAFB only revealed that partial flower thinning $(0+42)$ increased the subsequent development of total number of flower buds, flower buds per node, and flower buds on the proximal five nodes of shoots $15.0-30.0 \mathrm{~cm}$ in length but not on shoots $5.0-7.0 \mathrm{~cm}$ in length. The location and number of flower buds could affect degree of crop damage due to frosts. Because proximal flowers on shoots are the last to open (Spencer et al., 1975) they are less likely to be damaged from frosts which occur during the bloom period. Bloom thinning would also increase bloom density for the following season which would increase the need for flower thinning but give a larger number of flower buds to go through the winter. In addition, Byers et al. (1994) have
Table 2. Shoot number per limb and percent distribution of shoots by length relative to time of thinning of 'Redhaven' peach ${ }^{\mathrm{z}}$ Virginia.

\begin{tabular}{|c|c|c|c|c|c|}
\hline \multirow[b]{2}{*}{ Treatment } & \multirow[b]{2}{*}{ Shoots/limb } & \multirow{2}{*}{$\begin{array}{c}\text { Shoots } / \mathrm{cm}^{2} \\
\text { limb xsa }\end{array}$} & \multicolumn{3}{|c|}{ Percent distribution by length } \\
\hline & & & $\leq 8.0 \mathrm{~cm}$ & $>8.0<20.0 \mathrm{~cm}$ & $\geq 20.0 \mathrm{~cm}$ \\
\hline \multicolumn{6}{|l|}{ Thinned (DAFB)y } \\
\hline $0+42$ & 53.4 & 6.24 & 41.7 & 32.3 & 25.9 \\
\hline $14+42$ & 65.7 & 6.73 & 47.2 & 32.0 & 20.8 \\
\hline $28+42$ & 46.8 & 6.19 & 48.0 & 32.4 & 19.6 \\
\hline 42 & 67.7 & 6.88 & 48.8 & 27.3 & 23.9 \\
\hline 56 & 61.0 & 5.71 & 57.0 & 27.3 & 15.7 \\
\hline Unthinned (U) & 53.0 & 5.69 & 49.6 & 31.4 & 18.9 \\
\hline$P$ value & & & \multicolumn{3}{|c|}{$*$ Pearson $\chi^{2}$ test of homogeneity ${ }^{\mathrm{x}}$} \\
\hline All thinning trts & & & \multirow{5}{*}{\multicolumn{2}{|c|}{$\begin{array}{l}\text { All thinning trts } \\
(0+42) \text { vs. } U \\
42 \text { vs. } U \\
(0+42) \text { vs. } 42\end{array}$}} & 0.0160 \\
\hline Linear & 0.6483 & 0.8195 & & & 0.0940 \\
\hline$(0+42)$ vs. $U$ & 0.9814 & 0.7596 & & & 0.2540 \\
\hline 42 vs. U & 0.3746 & 0.4929 & & & 0.1850 \\
\hline$(0+42)$ vs. 42 & 0.3875 & 0.7125 & & & \\
\hline
\end{tabular}

${ }^{\mathrm{z}}$ Flowers or fruit initially thinned to $6.5 \mathrm{~cm}$ apart at bloom, 14 DAFB, and 28 DAFB then adjusted to $13 \mathrm{~cm}$ apart at 42 DAFB. Fruit thinned once to $13 \mathrm{~cm}$ apart at $42 \mathrm{DAFB}$ and 56 DAFB.

yDays after full bloom.

${ }^{\mathrm{x}}$ Fienberg (1977). 
Table 3. Flower bud development on shoots of varying lengths relative to thinning time of 'Redhaven' peach ${ }^{z}$ Virginia.

\begin{tabular}{|c|c|c|c|c|c|c|c|c|c|}
\hline \multirow[b]{2}{*}{ Treatment } & \multicolumn{3}{|c|}{ Flower buds/shoot } & \multicolumn{3}{|c|}{ Flower buds/node } & \multicolumn{3}{|c|}{ Flower buds/prox. 5 nodes } \\
\hline & $5.1-7.6 \mathrm{~cm}$ & $15.2-20.3 \mathrm{~cm}$ & $25.4-30.5 \mathrm{~cm}$ & $5.1-7.6 \mathrm{~cm}$ & $15.2-20.3 \mathrm{~cm}$ & $25.4-30.5 \mathrm{~cm}$ & $5.1-7.6 \mathrm{~cm}$ & $15.2-20.3 \mathrm{~cm}$ & $25.4-30.5 \mathrm{~cm}$ \\
\hline \multicolumn{10}{|l|}{ Thinned (DAFB)y } \\
\hline $0+42$ & 5.2 & 10.0 & 17.7 & 0.66 & 0.89 & 1.00 & 2.8 & 4.0 & 4.6 \\
\hline $14+42$ & 4.4 & 7.4 & 14.5 & 0.55 & 0.63 & 0.77 & 2.0 & 2.0 & 3.5 \\
\hline $28+42$ & 4.3 & 7.5 & 14.1 & 0.54 & 0.60 & 0.73 & 2.1 & 1.5 & 3.3 \\
\hline 42 & 5.5 & 7.2 & 13.9 & 0.69 & 0.61 & 0.77 & 2.8 & 1.8 & 2.7 \\
\hline 56 & 3.7 & 6.6 & 13.3 & 0.45 & 0.52 & 0.65 & 1.5 & 1.1 & 2.7 \\
\hline Unthinned (U) & 2.8 & 6.1 & 9.0 & 0.35 & 0.47 & 0.48 & 1.0 & 1.5 & 1.6 \\
\hline \multicolumn{10}{|l|}{$P$ value } \\
\hline \multicolumn{10}{|l|}{ All thinning trts } \\
\hline Linear & 0.0859 & 0.0001 & 0.0041 & 0.0476 & 0.0001 & 0.0001 & 0.0172 & 0.0001 & 0.0002 \\
\hline$(0+42)$ vs. $U$ & 0.0001 & 0.0001 & 0.0001 & 0.0001 & 0.0001 & 0.0001 & 0.0001 & 0.0001 & 0.0001 \\
\hline 42 vs. U & 0.0001 & 0.1325 & 0.0006 & 0.0001 & 0.0110 & 0.0001 & 0.0001 & 0.5390 & 0.0303 \\
\hline$(0+42)$ vs. 42 & 0.5654 & 0.0001 & 0.0044 & 0.5256 & 0.0001 & 0.0003 & 0.9407 & 0.0001 & 0.0002 \\
\hline
\end{tabular}

${ }^{2}$ Flowers or fruit initially thinned to $6.5 \mathrm{~cm}$ apart at bloom (0), 14 DAFB, or 28 DAFB then adjusted to $13 \mathrm{~cm}$ apart at 42 DAFB. Fruit thinned once to $13 \mathrm{~cm}$ apart at 42 DAFB or 56 DAFB.

${ }^{y}$ Days after full bloom.

shown that hardiness of bloom thinned trees is increased.

Expt. 2. Airblast sprayer application of AMADS was effective for providing partial thinning of peach trees, with the degree of thinning linearly related to chemical concentration (Table 4). Fruit on flower-thinned trees were larger by adjustment thinning time. As a result, all chemical thinning treatments increased fruit size at harvest, largely as a result of earlier fruit number reduction per tree than by hand thinning (Table 5). With the exception of the $7.5 \mathrm{~mL} \cdot \mathrm{L}^{-1}$ rate, all chemical thinning treatments reduced total yield compared to trees conventionally thinned by hand during the post-bloom period. All levels of chemical flower thinning increased the percentage of fruit in the larger fruit size categories (Table 6).

\section{Discussion}

Given current economic pressures to increase fruit size, it is critical to exploit the potential size benefit derived from bloom thinning. However, bloom thinning strategies must take into account the risks of unpredictable fruit set during the post-bloom period. Our research demonstrates that a viable strategy is to perform a partial bloom thinning during the bloom period, and, once set is determined, adjust crop load to the desired level.

Partial flower thinning of peach at bloom followed by adjustment thinning at 42 DAFB was superior to a similar amount of more traditional thinning accomplished entirely at 42 DAFB for increasing fruit size, leaf and shoot development, and flower bud formation. This study documents that this previously proposed thinning strategy (Byers et al., 1984; Weinberger, 1941) provides the desired benefits while providing for flexibility to manage certain risks such as variable fruit set and late spring freezes. In addition, partial flower thinning can be accomplished by chemical means, in this case by airblast application of AMADS. At the $7.5 \mathrm{~mL} \cdot \mathrm{L}^{-1}$ rate, AMADS was effective to achieve partial thinning of flowers, increase fruit size without decreasing total yield, and increase flower bud formation. The specific rate may vary from site-to-site and year-to-year.

The economic benefit of thinning on increased fruit size is derived from a higher price received for larger fruit, assuming yield is not decreased. If the increase in size of

Table 4. Influence of 1-aminomethanamide dihydrogen tetraoxosulfate (AMADS) when applied at full bloom on number of flowers or fruit of 'Golden Queen' peach ${ }^{2}$, New Zealand.

\begin{tabular}{|c|c|c|c|c|c|c|}
\hline \multirow[b]{2}{*}{$\begin{array}{l}\text { Concn } \\
\left(\mathrm{mL} \cdot \mathrm{L}^{-1}\right)\end{array}$} & \multicolumn{2}{|c|}{ Pre-thinning $^{y}$} & \multicolumn{2}{|c|}{ Reference date } & \multicolumn{2}{|c|}{ Post-adjustment thinning } \\
\hline & $\begin{array}{c}\text { Limb xsa } \\
\left(\mathrm{cm}^{2}\right)\end{array}$ & $\begin{array}{c}\text { Flowers } / \mathrm{cm}^{2} \\
\text { limb xsa }\end{array}$ & $\begin{array}{l}\text { Fruit } / \mathrm{cm}^{2} \\
\text { limb xsa }\end{array}$ & $\begin{array}{c}\text { Fruit/100 } \\
\text { flowers }\end{array}$ & $\begin{array}{l}\text { Fruit diam } \\
(\mathrm{mm})^{\mathrm{x}}\end{array}$ & $\begin{array}{c}\text { Fruit } / \mathrm{cm}^{2} \\
\text { limb xsa }\end{array}$ \\
\hline 0 & 4.0 & 44.3 & 9.1 & 19.3 & 33.4 & 4.9 \\
\hline 7.5 & 4.6 & 41.6 & 5.7 & 14.2 & 34.5 & 3.8 \\
\hline 10.0 & 4.2 & 40.8 & 3.9 & 8.8 & 36.9 & 3.0 \\
\hline 12.5 & 4.0 & 38.6 & 2.5 & 6.1 & 36.4 & 2.1 \\
\hline 15.0 & 4.5 & 46.4 & 2.6 & 6.5 & 36.6 & 2.0 \\
\hline Linear & 0.5756 & 0.8938 & 0.0001 & 0.0001 & 0.0007 & 0.0001 \\
\hline
\end{tabular}

${ }^{\mathrm{z}}$ AMADS applied at $73 \%$ full bloom with an airblast sprayer delivering $2100 \mathrm{~L} \cdot \mathrm{ha}^{-1}$. Adjustment thinning performed by hand $\approx 6$ weeks after treatment.

yPre-thinning measurements taken immediately prior to treatment; reference date measurements taken 6 weeks after treatment and prior to adjustment thinning; post- adjustment thinning measurements taken 7 weeks after treatment.

${ }^{\mathrm{x}}$ Average diameter of all fruit remaining on tagged limbs as measured $5 \mathrm{~d}$ after adjustment thinning.

Table 5. Influence of 1-aminomethanamide dihydrogen tetraoxosulfate (AMADS) when applied during the bloom period on subsequent yield and fruit weight of 'Golden Queen' peach ${ }^{2}$, New Zealand.

\begin{tabular}{lccc}
\hline \hline Concn $\left(\mathrm{mL} \cdot \mathrm{L}^{-1}\right)$ & Total yield $(\mathrm{kg})$ & Fruit/tree & Fresh wt/fruit $(\mathrm{g})$ \\
\hline 0 & 42.5 & 356 & 125.6 \\
7.5 & 41.4 & 309 & 135.3 \\
10.0 & 35.3 & 263 & 139.0 \\
12.5 & 20.7 & 128 & 163.0 \\
15.0 & 25.2 & 158 & 159.0 \\
Linear & 0.0144 & 0.0036 & 0.0011 \\
\hline
\end{tabular}

${ }^{\mathrm{z} A M A D S}$ applied at $73 \%$ full bloom with an airblast sprayer delivering $2100 \mathrm{~L} \cdot \mathrm{ha}^{-1}$. Adjustment thinning performed by hand $\approx 6$ weeks after treatment.

Table 6. Percent distribution of fruit by diameter as influenced by 1-aminomethanamide dihydrogen tetraoxosulfate (AMADS) applied at full bloom of 'Golden Queen' peach", New Zealand

\begin{tabular}{lcccc}
\hline \hline & \multicolumn{4}{c}{ \% Distribution by diam } \\
\cline { 2 - 5 } Concn $\left(\mathrm{mL} \cdot \mathrm{L}^{-1}\right)$ & $\leq 57 \mathrm{~mm}$ & $57-64 \mathrm{~mm}$ & $64-72 \mathrm{~mm}$ & $>72 \mathrm{~mm}$ \\
\hline 0 & 7.5 & 42.5 & 41.3 & 8.8 \\
7.5 & 5.0 & 28.8 & 57.5 & 8.8 \\
10.0 & 5.0 & 21.3 & 58.8 & 15.0 \\
12.5 & 1.3 & 5.0 & 40.0 & 53.8 \\
15.0 & 5.0 & 20.0 & 46.3 & 28.8 \\
$P$ value & & $<0.0001$ & &
\end{tabular}

${ }^{\mathrm{z}} \mathrm{AMADS}$ applied at $73 \%$ full bloom with an airblast sprayer delivering $2100 \mathrm{~L}^{\mathrm{ha}}{ }^{-1}$. ${ }^{y}$ Based on the Pearson $\chi^{2}$ test of homogeneity (Fienberg, 1977). 
cial price structure for processing peach fruit in the year data were collected, \$0.55 (NZ) per kilogram was paid for fruit larger than $64.0 \mathrm{~mm}$ in diameter while $\$ 0.35$ (NZ) per kilogram was paid for fruit $57.0-64.0 \mathrm{~mm}$ in diameter (S. Tustin, personal communication). Thus, the increase in fruit size evident in the $7.5 \mathrm{~mL} \cdot \mathrm{L}^{-1}$ treatment did increase crop value because total yield was not decreased. In the other thinning treatments, the increased value of fruit of larger size may have been offset by the decrease in total yield.

In summary, partial flower thinning is a cultural practice that has the potential to provide economic benefits in peach production. However, the ultimate application must be determined for specific areas or cultivars, price structures for given fruit sizes, economic yields required, potential for dormant and spring freezes, thinning costs, and labor availability.

\section{Literature Cited}

Batjer, J.P. and H.H. Moon. 1943. Thinning apples and peaches with blossom-removal sprays. Proc. Amer. Soc. Hort. Sci. 43:43-46.

Byers, R.E. 1988. Peach bloom thinning with desiccating chemicals, p. 662-663. In: N.F. Childers and W.B. Sherman (eds.). The Peach. Somerset Press, N.J.

Byers, R.E. 1989. Peach thinning, p. 70-72. In: S.C. Myers (ed.). Peach production handbook, Univ. of Georgia Coop. Ext. Ser. Hdbk., No. 1.
Byers, R.E. and C.G. Lyons, Jr. 1983. Chemical peach thinning with surfactants and ammonium nitrate. J. Hort. Sci. 58:517-519.

Byers, R.E. and C.G. Lyons, Jr. 1984. Flower thinning of peach with desiccating chemicals. HortScience 19:545-546.

Byers, R.E. and C.G. Lyons, Jr. 1985. Peach flower thinning and possible sites of action of desiccating chemicals. J. Amer. Soc. Hort. Sci. 110: 662-667.

Byers, R.E., C.G. Lyons, Jr., and S.J. Donohue. 1985. Effect of chemical deposits from spraying adjacent rows on efficacy of peach bloom thinners. HortScience 20:1076-1078.

Byers, R.E. and R.P. Marini. 1994. Influence of blossom and fruit thinning on peach flower bud tolerance to an early spring freeze. HortScience 29:146-148.

Corelli-Grappadelli, L. and D.C. Coston. 1991. Thinning pattern and light environment in peach tree canopies influence fruit quality. HortScience 26:1464-1466.

Dorsey, M.J. and R.L. McMunn. 1926. The development of the peach seed in relation to thinning. Proc. Amer. Soc. Hort. Sci. 23:402-413.

Farley, A.J. 1923. Factors that influence the effectiveness of peach thinning. Proc. Amer. Soc. Hort. Sci. 20:145-151.

Fienberg, S.E. 1977. The analysis of cross-classified data. MIT Press, Cambridge, Mass.

Feucht, W. 1955. Development, morphology, and topography of peach flower buds. Dissertation. Stuttgart-Hohenheim.

Gardner, V.R., R.E. Marshall, and H.D. Hootman. 1928. Size of peaches and size of crop. Mich. St. Coll. Agr. Expt. Sta. Spec. Bul. No. 184.
Havis, A.L. 1962. Effect of time of fruit thinning of Redhaven peach. Proc. Amer. Soc. Hort. Sci. 80: $172-176$.

Hoffman, M.B. and A. van Doren. 1945. Some results in thinning peaches with a blossom removal spray. Proc. Amer. Soc. Hort. Sci. 46:173-177.

Murneek, A.E. and A.D. Hibbard. 1944. Results of thinning peaches with Elgetol and switches. Proc. Amer. Soc. Hort. Sci. 45:69-71.

Myers, S.C. 1986. Effect of thinning time on the subsequent development of fruit, shoots, and flower buds of peaches. HortScience 21:680.

Myers, S.C., A. King, and A.T. Savelle. 1993. Bloom thinning of 'Winblo' peach and 'Fantasia' nectarine with monocarbamide dihydrogensulfate. HortScience 28:616-617.

Rieger, M. and F. Marra. 1994. Responses of young peach trees to root confinement. J. Amer. Soc. Hort. Sci. 119:223-228.

Spencer, S. and G.A. Couvillon. 1975. The relationship of node position to bloom date, fruit size, and endosperm development of the peach, Prunus persica (L.) Batsch cv. Sullivan's Elberta. J. Amer. Soc. Hort. Sci. 100:242244.

Tukey, H.B. and O. Einset. 1939. Effect of fruit thinning on size, color, and yield of peaches and on growth and blossoming of the tree. Proc. Amer. Soc. Hort. Sci. 36:314-319.

Weinberger, J.H. 1931. The relation of leaf area to size and quality of peaches. Proc. Amer. Soc. Hort. Sci. 28:18-22.

Weinberger, J.H. 1941. Studies on time of peach thinning from blossoming to maturity. Proc. Amer. Soc. Hort. Sci. 38:137-40. 